ORIGINAL ARTICLE

\title{
The effect of pre-season football training on hematological parameters of well-trained young male football players
}

\author{
Gökmen Özen ${ }^{1 \mathrm{ACDE}}$, Özdermir Atar ${ }^{1 \mathrm{ABE}}$, Hüseyin Ö. Yurdakul ${ }^{1 \mathrm{ADE}}$, Bayram Pehlivan ${ }^{2 \mathrm{AB}}$, Hürmüz Koç ${ }^{1 \mathrm{ABD}}$ \\ ${ }^{1}$ Çanakkale Onsekiz Mart University, Çanakkale,Turkey \\ ${ }^{2}$ İstanbul Gelişm University, Istanbul,Turkey
}

Authors' Contribution: A -Study design; B -Data collection; C -Statistical analysis; D -Manuscript Preparation; E Funds Collection

$\begin{array}{ll}\text { Abstract } & \\ \text { Purpose: } & \text { The purpose of this study was to examine the effect of metabolic stress created by 6-week football } \\ & \text { training applied in the pre-season period on circulation and hematological parameters of well-trained } \\ & \text { male football players. } \\ \text { Material: } & \text { Fourteen male football players who competed in the U19 category of a football team in Turkish Football } \\ & \text { Super League participated in the study voluntarily. In the study, players'systolic- diastolic blood pressures } \\ \text { and resting heart rates were measured and their blood samples were taken before and after the 6-week } \\ \text { training period. Laboratory analysis was made to determine counts and concentration percentage of } \\ \text { erythrocyte, leukocyte, and platelet sub-parameters. Wilcoxon Signed-Rank test was performed to } \\ \text { determine the difference between pre and post measurements. } \\ \text { Our findings indicated that baseline mean values of lymphocyte, mean cell hemoglobin, and mean } \\ \text { corpuscular hemoglobin concentration were significantly higher than posttest mean values. The mean } \\ \text { of diastolic blood pressure and resting heart rate measured before the preseason training camp were } \\ \text { lower than their posttest mean values (p >.05). } \\ \text { It is thought that the decrease in the mean values of diastolic blood pressure and resting heart rate } \\ \text { caused by the effect of regular training during the preseason training period, while the increase in the } \\ \text { mean values of mean cell haemoglobin and mean corpuscular haemoglobin concentration caused by } \\ \text { the increased oxygen demand of the metabolism during the training period. } \\ \text { blood, football, hematology, heart, preseason, training. }\end{array}$

\section{Introduction}

Football is a highly popular team sport with millions of interested people compared to other sports branches. Also, football is a sports activity that is loved by most children and youth in many countries. Most of them dream of becoming a successful footballer in the future but the realization of their dream depends on their talent, physical and motor skill development [1]. Athletic performance in football develops depending on many factors such as technical, tactical, biomechanical, mental, physical and physiological [2]. Since football is a particularly demanding sport that requires high effort and motor skill from players, long-term training plans need to be made. Especially the pre-season training period plays an important role in the success of both teams and players in football. The pre-season period in football is a critical period to maximize the physical performance of players and prepare them for an intense match season [3]. Therefore, the high-intensity endurance and strength training programmes, maximizing the physical performance of athletes during the match season, are applied in pre-season training camps during six or eight weeks in summer seasons. The training load intensity in this period creates excessive stress in metabolism and accordingly, physical, and physiological changes occur in the organism [4].

(c) Gökmen Özen, Özdermir Atar, Hüseyin Ö. Yurdakul,

Bayram Pehlivan, Hürmüz Koç, 2020

doi:10.15561/26649837.2020.0605
Playing football is a physical activity that includes not only long-term physical efforts but also intermittent high-intensity physical efforts. When the studies on football players are examined, it is seen that daily intense football training positively affect various physiological systems such as musculoskeletal, nervous, immune, and metabolic systems. One of the most practical ways to examine these effects is to investigate the biochemical and blood parameters of players [5,6]. Exercise, depending on its intensity, creates several stress conditions in the human organism. These stress conditions have various physiological and metabolic effects. Cardiac output and haematological analysis are used as the most basic and practical indicator of physical stress to which an individual is exposed to during physical exercises. The levels of cells, nutrients and hormones in the blood are examined for hematological analysis while resting heart rate, systolic - diastolic blood pressure values are examined for cardiac data. Many researchers who examined the hematologic analysis of the athletes reported that regular exercises have different effects on their blood cell levels. Additionally, they stated that these differences depend on both the frequency, intensity, type and time of the exercise and the physical and physiological status of the subjects participating in the study [7-10]. Doing regular exercise provides an increase in the heart rate volume and accordingly, resting heart rate (bpm) decreases. However, the maximum heart rate $(\mathrm{bpm})$ reached during the 
exercise does not significantly change. The main factors that determine systolic blood pressure, arterial blood pressure are cardiac output and total peripheral resistance. Peripheral resistance decreases during exercise. Although peripheral resistance decreases, systolic blood pressure increases. The reason for this increase is the increase in heart rate volume. Diastolic blood pressure may decrease or remain constant with decreasing peripheral resistance during aerobic exercise [11]

In literature, it was stated that hematological parameters are affected by the age, environment and nutritional habits of the person, as well as the frequency, intensity, type, duration and of physical activity and exercise $[12,13]$. However, in the literature studies that examined the relationship between regular exercises and blood hematotology numerous researchers stated that regular exercise affects blood cells and parameters $[9,14$, 15], while some researchers stated that regular exercise does not affect on blood cells and parameters [16]. This discrepancy in the literature has been one of the reasons we do this study. In this context, examining the change in hematological parameters during the intensive training period applied in the pre-season camp periods in football will provide important feedback to evaluate the effects of the training during this period on athletes. To this end, the purpose of this study was to investigate the effect of the 6-week pre-season football training that caused the metabolic stress in the young elite football players.

\section{Materials and Methods}

Participants.

Fourteen male young football players aged 17-18 participated in the study voluntarily. Participants competed in the U19 category of a football team in Turkish Football Super League. They participated in the training regularly 3 days a week in the last five years. Written informed consent forms were obtained from all participants.

\section{Research Design.}

This study was carried out in a pre-season six-week preparatory camp of a U19 football team that competed Turkish Football Super League. This research was conducted in accordance with the Helsinki Declaration

During the pre-season camp period, a six-week

training program including technical, tactical and physical condition training was applied to players. This training program was prepared by team coaches and performed six days each week. Workouts of players were performed three days of a week, both morning and afternoon while other days performed as one workout in the morning (120-min daily training units). A standard diet program prepared by specialist dieticians was applied to the players throughout this camp period. The players were asked to follow the diet program during this period and not to use any medications or supplements. The data for this study was obtained from a standardized data extraction form, body height, body mass, systolic blood pressure (SBP), diastolic blood pressure (DBP) and resting heart rate (HRrest) measurements, and hematological analysis. The standardized data extraction form was used to collect demographic information.

\section{Data Collection.}

Anthropometric and cardiac measurements were made 24 hours before and after the pre-season training period. Blood samples were taken for analysis of blood hematological parameters at the same time. Body height was measured in $\mathrm{cm}$ by using a stadiometer and body mass was measured in $\mathrm{kg}$ using by a digital body weight scale. Participants' resting heart rate (HRrest), systolic blood pressure (SBP) and diastolic blood pressure (DBS) was measured with Microlife BP 3 blood pressure measuring devices [17].

Hematological parameters were obtained from blood samples taken for general health screening of athletes.

Their blood samples were taken from the forearm antecubital vein at 9:00 am following an eight-hour fast. The blood samples were taken two times both before and after the training programs. $5 \mathrm{ml}$ of the blood samples were collected by using sterile EDTA vacuum tubes. Blood analysis was immediately performed included: Erythrocyte (RBC), Hemoglobin( HGB), hematocrit $(\mathrm{HCT})$, mean cell hemoglobin $(\mathrm{MCH})$, mean cell hemoglobin concentration (MCHC), mean corpuscular volume (MCV) and red blood cell distribution width (RDW), WBC, lymphocytes (LY\%), neutrophil percentage (NE\%), monocyte percentage $(\mathrm{MO} \%)$, basophil percentage (BA\%) and platelet (PLT).

Statistical Analysis.

Statistical analyses were carried out using SPSS statistic software package ver. 22.0 (IBM Corp., Armonk, NY, USA). Data are presented as means with a standard deviation $(M \pm S D)$. Shapiro-Wilk $W$ test was used to determine that data was acceptable with regard to homogeneity. As variances showed non-normal distribution, the Wilcoxon signed-rank test was performed to compare the pre and posttest measurements. The level of statistical significance was set at 0.05 .

\section{Results}

Basic demographic characteristics of the participants were present in Table 1.

Table 1. Basic demographic characteristics of the participants $(n=14)$

\begin{tabular}{lllll}
\hline Variables & Min & Max & Mean & SD \\
\hline Age (Year) & 17 & 19 & 17,89 & 0,62 \\
$\begin{array}{l}\text { Training Age } \\
\text { (Year) }\end{array}$ & 5 & 13 & 8,7 & 3,58 \\
Heigth (cm) & 164 & 194 & 177,4 & 6,85 \\
Weigth (kg) & 56 & 108 & 71,7 & 10,66 \\
\hline
\end{tabular}

Figure 1 illustrates pre-test and post-test differences in SBP, DBP, and HRrest parameters. The results of our statistical analysis indicated that there were significant differences between pre-tests and the post-tests in DBP and HRrest mean values. However, there was no significant difference between the pre- and post-test SBP mean values $(\mathrm{z}=1.89, \mathrm{p}=0.58)$. Pre-test DBP values $136.57 \pm 7.34)$ was 
found significant decreased $(\mathrm{z}=2.63, \mathrm{p}=0.009)$ compared with the post-test means $(132.79 \pm 2.66)$. Pre-test HRrest values $(73.7 \pm 3.81)$ were significantly decreased $(\mathrm{z}=3.19$, $\mathrm{p}=0.001)$ compared with the posttest means (67.0 \pm 3.88$)$.

A comparison of the erythrocyte parameters for the pre- and post-tests are shown in Table 2. The results of the Wilcoxon signed-rank test indicated that there were significant differences between pre- and post-tests values in $\mathrm{MCH}$ and $\mathrm{MCHC}$ parameters. Pre-test $\mathrm{MCH}$ $(27.93 \pm 1.46)$ and $\mathrm{MCHC}(32.19 \pm 0.45)$ mean values were found significantly increased compared with the post-test
$\mathrm{MCH}(28.44 \pm 1.22)$ and MCHC (32.19 \pm 0.45$)$ mean values $(\mathrm{p}<0.05)$. However, there were no significant differences between pre- and post-test mean values of RBC, HGB, HCT, MCV and RDW ( $\mathrm{p}>0.05)$. A comparison of the leukocyte parameters for the pre- and post-tests are shown in Table 3. The results of Wilcoxon signed-rank test indicated that there were no significant differences between pre- and post-tests mean values of WBC, LY\%, $\mathrm{NE} \%, \mathrm{MO} \%$ ve $\mathrm{BA} \%$ parameters $(\mathrm{p}>0.05)$.

A comparison of the pre- and post-tests platelet mean values are shown in Table 3. The results of the Wilcoxon

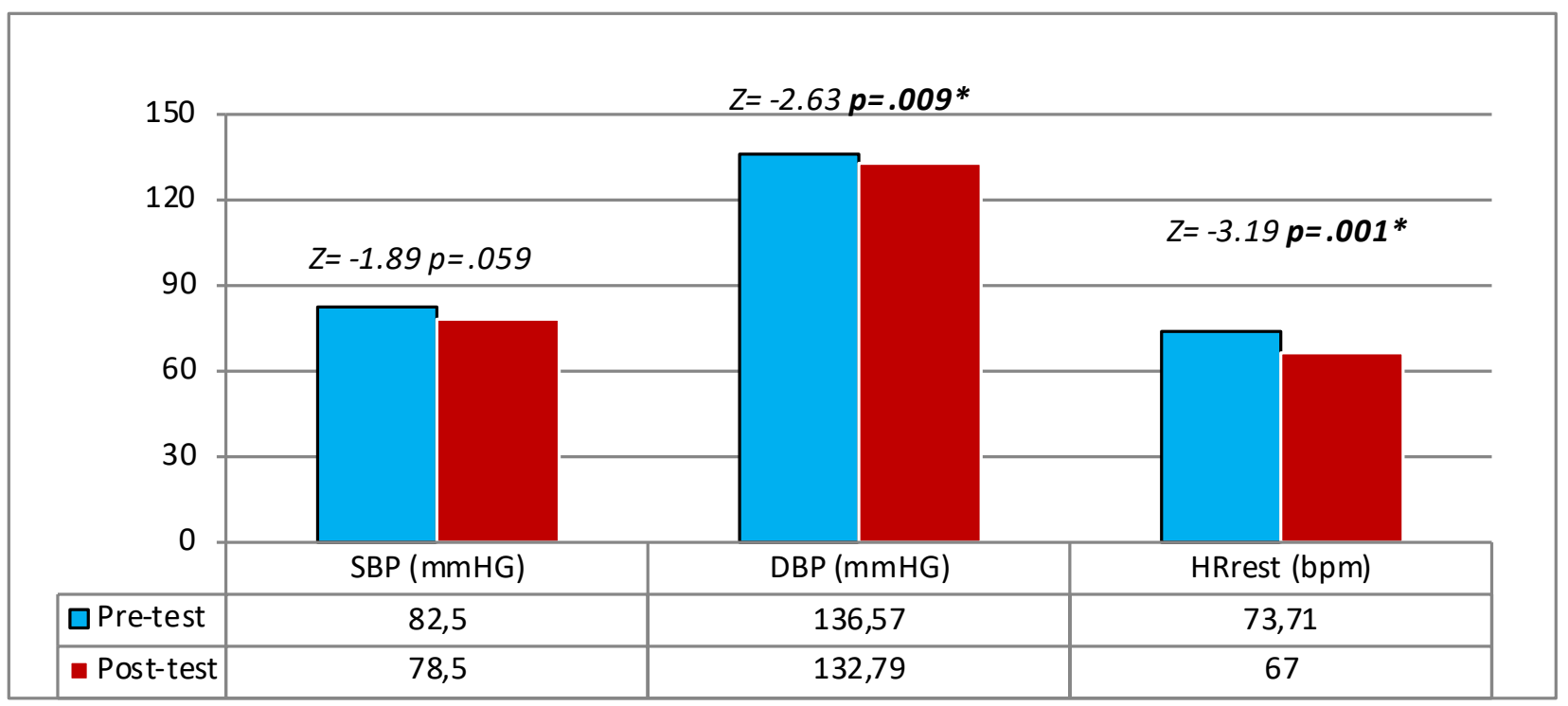

Figure 1. Comparison of mean SBP, DBP and HRrest pre-test and posttest values.

Table 2. Comparison of for the pre- and post-tests results in erythrocyte parameters

\begin{tabular}{|c|c|c|c|c|c|c|}
\hline \multirow{2}{*}{ Parameters } & \multicolumn{2}{|c|}{ Pre-Test } & \multicolumn{2}{|c|}{ Post-Test } & \multirow{2}{*}{$\mathbf{Z}$} & \multirow{2}{*}{$\mathbf{P}$} \\
\hline & $M$ & Sd & $M$ & Sd & & \\
\hline $\mathrm{RBC}\left(10^{\wedge} 6 / \mathrm{uL}\right)$ & 5.20 & 0.45 & 5.08 & 0.38 & -1.45 & 0.15 \\
\hline HGB (g/dL) & 14.49 & 0.94 & 14.45 & 0.59 & 0.00 & 1.00 \\
\hline HCT (\%) & 45.03 & 3.04 & 43.97 & 2.10 & -1.13 & 0.25 \\
\hline $\mathrm{MCV}(\mathrm{fL})$ & 86.71 & 3.87 & 87.00 & 3.28 & -0.31 & 0.97 \\
\hline $\mathrm{MCH}(p g)$ & 27.93 & 1.46 & 28.44 & 1.22 & -2.33 & $0.02 *$ \\
\hline MCHC (g/dl) & 32.19 & 0.45 & 32.82 & 0.43 & -3.11 & $0.02 *$ \\
\hline RDW (\%) & 13.67 & 1.18 & 13.57 & 0.42 & -0.75 & 0.45 \\
\hline
\end{tabular}

Note: ${ }^{*} p<0.05$, RBC: erythrocyte, HGB: hemoglobin, HCT: hematocrit, $\mathrm{MCH}$ : mean cell hemoglobin, MCHC: mean cell hemoglobin concentration, MCV: mean corpuscular volume, RDW: red blood cell distribution width.

Table 3. Comparison of for the pre- and post-tests results in leukocyte parameters

\begin{tabular}{|c|c|c|c|c|c|c|}
\hline \multirow{2}{*}{ Parameters } & \multicolumn{2}{|c|}{ Pre-Test } & \multicolumn{2}{|c|}{ Post-Test } & \multirow{2}{*}{ Z } & \multirow{2}{*}{$\mathbf{p}$} \\
\hline & $M$ & Sd & $M$ & Sd & & \\
\hline WBC $\left(\mathrm{K} / \mathrm{mm}^{3}\right)$ & 6.56 & 1.07 & 6.72 & 1.33 & -0.38 & 0.71 \\
\hline LY\% & 37.14 & 7.26 & 41.31 & 8.27 & -1.98 & 0.48 \\
\hline NE\% & 51.69 & 8.78 & 47.41 & 9.52 & -1.51 & 0.13 \\
\hline MO\% & 7.75 & 2.20 & 7.11 & 1.44 & -0.91 & 0.36 \\
\hline BA\% & 0.38 & 0.13 & 0.33 & 0.09 & -1.37 & 0.17 \\
\hline
\end{tabular}

Note: WBC: white blood cell, LY\%: lymphocytes percentage, NE\%: neutrophil percentage, MO\%: monocyte percentage, BA\%: basophil percentage 
Table 4. Comparison of for the pre- and post-tests of platelet mean values.

\begin{tabular}{lllllll}
\hline \multirow{2}{*}{ Parameters } & Pre-Test & \multicolumn{5}{c}{ Post-Test } \\
\cline { 2 - 7 } & $\mathbf{M}$ & Sd & M & Sd & p \\
\hline PLT $\left(\mathrm{K} / \mathrm{mm}^{3}\right)$ & 205,57 & 54,94 & 214,85 & 23,12 & $-1,13$ & 0,31 \\
\hline
\end{tabular}

Note: PLT: platelet

signed-rank test indicated that there was no significant difference between pre- and post-tests mean values of PLT $(\mathrm{p}>.05)$.

\section{Discussion}

The result of this study demonstrated that the 6-week intensive training program implemented in the pre-season preparatory camp for young footballers led to a decrease in HRrest and DBP, which are indicators of increased endurance. Scientific studies have indicated that there was a high correlation between increased aerobic endurance and decrease in HRrest values in many different sports disciplines [18]. In this regard, the decreasing in the players' mean of HRrest and DBP of at the end of the sixweek training period consistent with the previous reports. Gökdemir et al. [19] have determined that aerobic training which is applied three days a week for eight weeks has an impact which caused a drop in HRrest and DBP values. In another study conducted to determine the effect of the aerobic training program applied for six-weeks on the parameters of HRrest, SBP and DBP in athletes are revealed that there was a decrease in HRrest and SBP values due to the effect of training [18]. Kürkçü et al. [20] have also stated that there were significant decreases in SBP and HRrest parameters of athletes after the eightweek pre-season training. The results of these studies support our findings. The increase in the heart rate in regular exercises causes to increase in the heart stork volume and cardiac output. These cardiac changes also cause a decrease in heart rate at the resting time. During the aerobic exercise, DBP may decrease slightly due to the decrease in peripheral resistance while static exercises cause an increase in DBP. On the other hand, there is an increase in SKB values, despite the decrease in peripheral resistance during exercises. It is stated that the increase depends on the volume of the beat. It is stated that this increase is related to stroke volume [11].

In this study, it was observed that the differences in the mean values of the $\mathrm{MCH}, \mathrm{MCHC}$ parameters of the players before and after the training were significant while the differences in the RBC, HBG, HCT, MCV and RDW parameters were not significant. It is thought that the change in these parameters in football players depends on the level of physical activity performed and the increased oxygen demand of the metabolism during the training period. Blood volume and the amount of hemoglobin increase with exercise. While the number of hemoglobin increases, a decrease in hemoglobin concentration may occur due to the increase in plasma volume [11, 21, 22].

In the study of Hazar and Akyol [23] who examined the effect of regular training in runners, they found a significant difference between the pre and post measurements in $\mathrm{HGB}, \mathrm{MCV}$ and MCHC parameters of the runners and the ski runners only MCHC parameters. In another study, Karakuş et al. [24] have stated that exercises had a positive effect on erythrocyte parameters. They also emphasized that this positive effect on erythrocyte blood parameters was due to the exercise program applied. Bezci and Kaya [25] have reported that the increases in athletes' WBC, HGB, PLT, RBC, HCT and MCH values before and after maximal training were significant. Although these increases are reported to be due to plasma losses caused by exercise, it was also stated that intravenous hemolysis as a result of trauma caused by intense exercise may be the reason for the decrease in erythrocyte values [26]. Moreover, Koç et al. [18] reported that the erythrocyte parameters of athletes were higher than sedentary individuals depending on the level of physical activity. When the findings of these studies in the literature are examined, it is seen that there are differences with our findings. These differences are thought to result from differences in the sample groups and training methods. Because depending on the participants, the type, intensity and duration of the exercise, the effect of the exercise on hematological parameters may be different [13].

In this study, it was observed that the differences in the mean values of the $\mathrm{WBC}, \mathrm{LY} \%, \mathrm{NE} \%, \mathrm{MO} \%$ and $\mathrm{BA} \%$ parameters of the players before and after the training were not significant. There was an increase in WBC and LY\% mean values before and after training in football players, although it was insignificant. It is thought that this increase is due to the fact that the training done during the preparation period can resist the increasing stress in the metabolism and have a positive effect on the immune functions of the athletes regardless of the infection conditions. Because blood, consisting of red blood cells, white blood cells, platelets and plasma, plays a big role in protecting and regulation in the human body [27]. When the scientific studies of leukocyte and its sub-parameters are examined, it is seen that there is no common consensus about the effects of exercise on WBC values. However, it is seen that the studies supporting our findings are in the majority.

Banfi et al. [28] have reported that there is no significant difference in male rugby players' WBC value before and after the pre-season training camp. Hazar et al. [23] determined that there was no statistically significant change in WBC parameters after regular training in athletes and ski runners. Yeh et al. [29] stated that there was no statistically significant change in female and 
male athletes' WBC level before and after the 12-week exercise period. Ergün et al. [30] have found that aerobic exercises which are applied regularly three days a week do not affect WBC level in middle-aged men.In the study of Boylı et al. [31] declared that there was no significant increase in taekwondo athletes' WBC parameters in the preparation period training. These results in the literature are consistent with our research results. Koç et al. [18] determined that the mean values of WBC parameters were lower in sedentary individuals compared to their peers who do regular physical activity. In another study of Koç et al. [32], they have stated that the RBC value was higher in athletes who exercise regularly for five years than sedentary individuals and the WBC value was lower.

In this study, it was observed that the differences in players' the mean value of PLT before and after the training were not significant. In the literature, even though scientific findings are indicating that acute and chronic exercises cause an increase in the mean value of PLT the findings of some studies indicating that there is no significant increase in the mean value of PLT [26, 31, 33]. In the study of Boyli et al. [33] who investigated the effect of the preparatory period training on the hematological parameters, their findings revealed that taekwondo athletes' PLT mean value decreased due to the training performed. Hazar et al. [23] have stated that the difference between the pre and post-measurement values of the WBC, RBC and PLT parameters of the athletes participating in regular training is not statistically significant. The study of Çakmakçı [13] who conducted in the Taekwondo National Team to determine the change in the hematological parameters of WBC, RBC and PLT before and after the camp, he has stated that the change in the WBC and PLT values was not significant, but the change in the $\mathrm{RBC}$ value was significant. Although there is no consensus in the literature, the findings of some studies support our results.

\section{Conclusion}

As a result of this research, there was a significant decrease in the DBP and HRrest values, which indicates the increase in the endurance of the intensive training program in the pre-season preparation camp for young footballers. the decreasing in these parameters is thought to be due to the effect of regular training. When the hematological parameters of young players are examined, it is seen that the mean values of the parameters with an increase, in general, are in the reference range envisaged for healthy adults. The increase in the $\mathrm{MCH}$ and $\mathrm{MCHC}$ levels of the athletes is considered as a change that occurs due to the increased oxygen demand of the metabolism during the training period.

\section{Acknowledgement}

We gratefully acknowledge the help of all the participant who took part in the study.

This study was presented in 16th International Sport Sciences Congress in Antalya/TURKEY, 2018.

\section{Conflict of interests}

The authors state that there is no conflict of interest

\section{References}

1. Taşkın C, Karakoç Ö, Nacaroğlu E, Budak C. Futbolcu çocuklarda seçilmiş motorik özellikler arasındaki ilişkinin incelenmesi [The investigation of the relationship among selected motoric features of children soccer players]. Spor ve Performans Araştırmaları Dergisi, 2015; 6 (2): 101-107 (in Turkish) https://doi.org/10.17155/spd.74072

2. Aslan CS. Futbolda Dar Alan Oyunlari Ile Kosu Antrenmanlarinin Karsilastirilmasi: Fiziksel, Fizyolojik ve Teknik Özellikler. Published by LAP Lambert Academic Publishing; 2016. (in Turkish)

3. Mc Millan K, Helgerud J, Grant S. Newell J. Lactate threshold responses to a season of professional British youth soccer, British Journal of Sports Medicine. 2005; 39(7):432-436. https://doi.org/10.1136/bjsm.2004.012260

4. Baechle TR, Earle RW. Essentials of strength and conditioning, Human Kinetics, Champaign II; 2000.

5. Reilly T, Ekblom B. The use of recovery methods post-exercise. $J$ Sports Sci, 2005; 6: 619-27. https://doi.org/10.1080/02640410400021302

6. Anđelković M, Baralić I, Đorđević B, Stevuljević JK, Radivojević N, Dikić N, etal. Hematological And Biochemical Parameters In Elite Soccer Players During A Competitive Half Season. Journal of Medical Biochemistry, 2015;34:460-466. https://doi.org/10.2478/jomb-2014-0057

7. Jamurtas AZ, Fatouros IG, Deli CK, Georgakouli K, Poulios A, Draganidis D, et al. The effects of acute low-volume HIIT and aerobic exercise on leukocyte count and redox status. Journal of Sports Science \& Medicine, 2018; 17(3): 501-508.

8. Erkmen N, Kaplan T, Taşkin H. Profesyonel futbolcularin hazırlık sezonu fiziksel ve fizyolojik parametrelerinin tespiti ve karşılaştırılması [Professional soccer player's pre-season physical and physiological parameters: Comparison and determination]. Spormetre Beden Eğitimi ve Spor Bilimleri Dergisi, 2005; 3(4): 137-144 (in Turkish) https://doi.org/10.1501/Sporm_0000000056

9. Koç H. Aerobik antrenman programının erkek hentbolcularda bazı dolaşım ve solunum parametrelerine etkisi [Influence of aerobic training program on some respiratory and circulatory parameters in male handball players]. Selçuk Üniversitesi Beden Eğitimi ve Spor Bilimleri Dergisi, 2010;12(3): 185190 (in Turkish)

10.Koç $\mathrm{H}$. The comparison of blood lipid levels of athletes and sedentary college students. Pak J Med Sci. 2011; 27(3): 622625.

11.Uzun M. Cardiovascular System and Exercise. $J$ Cardiovasc Nurs, 2016;7:48-53. https://doi.org/10.5543/khd.2016.77487

12.Astrand PO, Rodalf K. Textbook of Work Physiology Physiological Bases of Exercise. New York: McGraw Hi 11 Book Company; 1986.

13.Çakmakçı E. Erkek Taekwondocularda Kamp Döneminin Bazı Hematolojik Parametreler Üzerine Etkileri [Effects of camp term on some hematological parameters in male taekwondoers]. Niğde Üniversitesi Beden Eğitimi ve Spor 
Bilimleri Dergisi, 2009; 3(1): 21-29 (in Turkish)

14.Duzova H, Karakoc Y, Gullu E, Gullu A, Koksal B, Esen B. The acute effects of single football match on whole blood viscosity and hematological variables in female soccer players. Biomedical Research, 2016; 27 (4): 1423-1425.

15.Kantyka J, Herman D, Roczniok RL. Effects of aqua aerobics on body composition, body mass, lipid profile, and blood count in middle-aged sedentary women. Human Movement, 2015; 16(1): 9-14. https://doi.org/10.1515/humo-2015-0020

16.Spiropoulos K, Trakada G. Hematologic and biochemical laboratory parameters before and after a marathon race. Lung, 2003; 181(2): 89-95. https://doi.org/10.1007/s00408-003-1009-y

17.Günay M, Tamer K, Cicioğlu İ. Spor Fizyolojisi ve Performans Ölçümü [Sports Physiology and Performance Measurement]. Ankara: Gazi Kitabevi; 2013. (in Turkish)

18.Koç H, Sarıtaş N, Büyükipekçi S. The comparison of hematological and blood levels of athletes with sedentary. Sağllk Bilimler Dergisi, 2010; 19: 196-201.

19.Gökdemir K, Koç H, Yüksel O. Aerobik antrenman programının üniversite ögrencilerinin bazı solunum ve dolasım parametreleri ile vücut yağ oranı üzerine etkisi [Effects of aerobic training program on respiration circulation and body fat ratio of university students]. Egzersiz Çevrim $\dot{I}_{c ̧ i}$ Dergisi, 2007; 1(1): 44-49. (in Turkish)

20.Kürkçü R, Hazar F, Atlı M, Kartal R. Sezon öncesi hazırlık dönemi antrenmanlarının güresçilerin solunum fonksiyonları kan basınc1 ve vücut kompozisyonuna etkisi [The effect of pre-season preparatory training on wrestlers' respiratory functions, blood pressure and body composition]. Türkiye Kick Boks Federasyonu Spor Bilimleri Dergisi, 2009; 1(2): 9-19. (in Turkish)

21.Powell KE, Thompson PD, Caspersen CJ, Kendrick JS. Physical Activity and the Incidence of Coronary Heart Disease. Annu Rev Public Health, 1987;8:253-287. https://doi.org/10.1146/annurev.pu.08.050187.001345

22.Mairbäurl H. Red blood cells in sports: effects of exercise and training on oxygen supply by red blood cells. Front Physiol, 2013;4.1-13. https://doi.org/10.3389/fphys.2013.00332

23. Hazar K, Akyol H. Atlet ve kayaklı koşucularda yapılan düzenli antrenmanların bazı kan parametrelerine etkisi [The effect of regular training on some blood parameters of athletes and crosscountry skiers]. Gaziantep Üniversitesi Spor Bilimleri Dergisi, 2019; 4(2): 211-221. (in Turkish) https://doi.org/10.31680/gaunjss.550225
24.Karakuş M, Koç H. The effect of moderate exercise on erythrocyte blood parameters in allogenic bone marrow transplant patients, Kinesiologia Slovenica, 2018; 24(2): 28-35.

25.Bezci Ş, Kaya Y. The analyze of hematological parameters of elite women taekwondoers before and after training. Pamukkale Journal of Sport Sciences, 2010; 1(2): 1-16.

26.Erdağ 1 K, Yüksel MF, Sevindi T. Elit kadın haltercilerde maksimal kuvvet antrenmanının hematolojik parametreler üzerine etkisi [The effects of maximal power training on hematologic parameters of female weight-lifter]. The Journal of Turkish Sport Sciences. 2018; 1(1): 41-48. (in Turkish)

27.Isaac LJ, Abah G, Akpan B, Ekaette IU. Hematological properties of different breeds and sexes of rabbits. Proceedings of the $18^{\text {th }}$ Annual Conference of Animal Science Association of Nigeria. 2013. P.24-27.

28.Banfi G, Del Fablo M, Mauri C, Corsi MM, Melegati G. Hematological parameters in higly elite rugby players during a competitive season. Clinical \& Laboratory Haematology, 2006; 28(3): 183-188. https://doi.org/10.1111/j.1365-2257.2006.00771.x

29. Yeh SH, Chuang H, Lin LW, Hsiao CY, Eng HL. Regular tai chi chuan exercise enhances functional mobility and CD4CD25 regulatory $\mathrm{T}$ cells. British Journal Of Sports Medicine. 2006; 40: 239-243. https://doi.org/10.1136/bjsm.2005.022095

30.Ergün M, Tengız I, Türk U, Şenışık S, Alioglu E, Yüksel O, et al. The effect of long term regular exercise on endothelial functions, inflammatory and thrombotic activity in middle aged, healthy men. J Sports Sci Med. 2006; 5(2): 266-275.

31.Boyalı E, Sevindi T, Yüksel MF, Demir H. The effects of preparation period exercises on the hematological parameters of the taekwondo athletes. Physical Education of Students, 2019; 23(1): 9-15. https://doi.org/10.15561/20755279.2019.0102

32.Koç H, Özen G, Abanoz H, Pulur A. Comparative analysis of hematological parameters in well-trained athletes and untrained men. Pedagogics, psychology, medical-biological problemsofphysicaltrainingandsports, 2018;22(5):260-264. https://doi.org/10.15561/18189172.2018.0506

33.Belviranli M, Okudan, N, Kabak B. The effects of acute high-intensity interval training on hematological parameters in sedentary subjects. Medical Sciences, 2017; 5(15): 1-7. https://doi.org/10.3390/medsci5030015 


\section{Information about the authors:}

Gökmen Özen; (Corresponding Author); https://orcid.org/0000-0001-5756-653X; gokmenozen44@gmail.com; Department of Physical Education and Sports Teaching, Faculty of Sport Sciences, Çanakkale Onsekiz Mart University; Çanakkale,Turkey.

Özdemir Atar; https://orcid.org/0000-0001-7941-2865; demiratar@gmail.com; Department of Coaching Education, Faculty of Sport Sciences, Çanakkale Onsekiz Mart University; Çanakkale,Turkey.

Hüseyin Ö. Yurdakul; https://orcid.org/0000-0001-6879-3658; hoyurdakul@gmail.com; Department of Physical Education and Sports Teaching, Faculty of Sport Sciences, Çanakkale Onsekiz Mart University; Çanakkale,Turkey.

Bayram Pehlivan; https://orcid.org/0000-0002-4469-795X; bpehlivan@gmail.com; İstanbul Gelişim University; İstanbul,Turkey.

Hürmüz Koç; https://orcid.org//0000-0003-2867-9775; hurmuzkoc@gmail.com; Department of Coaching Education, Faculty of Sport Sciences, Çanakkale Onsekiz Mart University; Çanakkale,Turkey.

Cite this article as:

Özen G, Atar Özdermir, Yurdakul HÖ, Pehlivan B, Koç H. The effect of pre-season football training on hematological parameters of well-trained young male football players. Pedagogy of Physical Culture and Sports, 2020;24(6):303-309. https://doi.org/10.15561/26649837.2020.0605

This is an Open Access article distributed under the terms of the Creative Commons Attribution License, which permits unrestricted use, distribution, and reproduction in any medium, provided the original work is properly cited (http://creativecommons.org/licenses/by/4.0/deed.en).

Received: 10.05.2020

Accepted: 20.06.2020; Published: 30.12.2020 